\title{
BIOLOGICAL IMPLICATIONS OF THE PHENOTYPIC PLASTICITY IN THE Schistosoma mansoni-Nectomys squamipes MODEL
}

\begin{abstract}
SUMMARY
The water-rat Nectomys squamipes is mostly important non-human host in schistosomiasis mansoni transmission in Brazil, due to its susceptibility, high abundance and water-contact pattern. During experimental infection of N. squamipes with Schistosoma mansoni, adult worms show phenotypic plasticity. This finding led us to investigate whether biological behavior is also affected. This was assessed comparing the biological characteristics of four S. mansoni strains: BE (State of Belém do Pará), CE (State of Pernambuco), CMO (State of Rio Grande do Norte) and SJ (State of São Paulo) using laboratory-bred N. squamipes. The infection was monitored by determination of the pre-patent period, fecal egg output, egg viability, intestinal egg count and, infectivity rate. No biological modification was observed in these parameters. Overall results highlight that $N$. squamipes was susceptible to several S. mansoni strains, suggesting that it might contribute to the maintenance of schistosomiasis mansoni in Brazil.
\end{abstract}

KEYWORDS: Schistosoma mansoni; Nectomys squamipes; Epidemiology; Biological study.

\section{INTRODUCTION}

Parasites have profound effects on host ecology and their effects are often influenced by the magnitude of host susceptibility to parasites. Wild rodents live in different environments causing them to be especially susceptible to a broad range of parasites. Schistosoma mansoni is the most widespread of the human-infecting schistosomes. However, rodents in both the Africa and the Neotropics also develop natural infection ${ }^{1,9,24,35}$. In addition, the possibility of closing the $S$. mansoni cycle without human participation had been demonstrated with rodents ${ }^{2}$ or bovine ${ }^{22}$ acting as final host. In Brazil, the water rat Nectomys squamipes (Rodentia:Sigmodontinae) is an important nonhuman host in schistosomiasis transmission, due to its susceptibility, high abundance, water-contact pattern ${ }^{6}$, and daily activities ${ }^{4}$. Epidemiological surveys have demonstrated naturally-infected $N$. squamipes in several places: Maranhão, Alagoas, Sergipe, Bahia, Minas Gerais, São Paulo, Paraná and Rio de Janeiro ${ }^{31}$. The role of $N$. squamipes in the transmission of schistosomiasis in the municipality of Sumidouro, Rio de Janeiro, Brazil, has been reported by biological, epidemiological and ecological studies ${ }^{6}$. The results showed that levels of infections did not change when the human population was treated with antiparasite drugs. The authors found in some occasions a positive correlation between infection rodent rates and infection human rates. Although schistosomiasis can provoke severe damages to humans, rodents are permissive hosts with life-long infections ${ }^{18}$, which do not affect their life $\operatorname{span}^{33}$ or reproductive capacity ${ }^{6}$. In addition, morphometric analysis of hepatic granulomas showed that all measurements were smaller in naturally infected $N$. squamipes compared to mice ${ }^{3}$. Another study made biological and histopathological comparisons between Brazilian laboratory-reared strains of S. mansoni (BH - Belo Horizonte, MG and SJ - São José dos Campos, SP) and newly strain (SR - Campinas, SP) ${ }^{38}$. The authors showed that at week eight post-infection, the new strain was less pathogenic than the other two, since a lower number of hepatic granulomas and a smaller granuloma size were found ${ }^{38}$. Earlier studies demonstrated that $N$. squamipes could also be used as an alternative animal model in basic biological studies on schistosomiasis ${ }^{20,34}$.

Host-induced morphological changes (phenotypic plasticity) have been described in parasitic flatworms which are maintained in different hosts rather than their natural ${ }^{25}$. Phenotypic plasticity also occurs in $S$. mansoni ${ }^{26}$. However, it remains to be seen whether the phenotypic plasticity has biological implications for this helminth. To this end, the course of $S$. mansoni infection was monitored in experimentalinfected N. squamipes.

\section{MATERIAL AND METHODS}

Animals husbandry - N. squamipes were bred from stock obtained from Laboratory of Biology and Control of Schistosomiasis mansoni, Department of Tropical Medicine, Oswaldo Cruz Institute 5 . Each rodent was housed conventionally in polypropylene cages $(40 \times 33 \mathrm{~cm})$ with

CNPq fellowship.

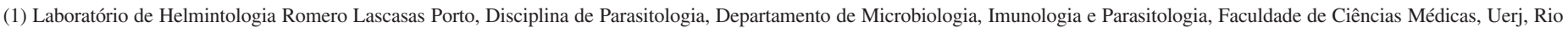
de Janeiro, RJ, Brasil.

(2) Laboratório de Helmintos Parasitos de Vertebrados, Instituto Oswaldo Cruz, Rio de Janeiro, RJ, Brasil.

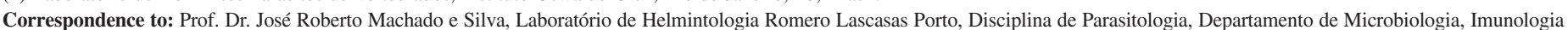

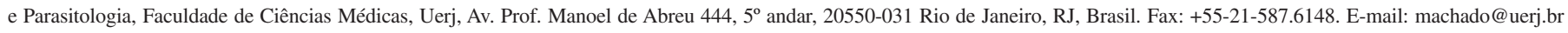




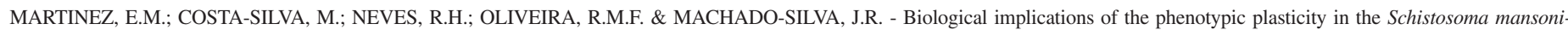
Nectomys squamipes model. Rev. Inst. Med. trop. S. Paulo, 50(4): 229-232, 2008.

stainless steel screen covers. Rodent chow (Nuvilab CR1, Colombo, Paraná, Brazil) and water were given ad libitum. The experiments reported here comply with ethical procedures with investigated animals ${ }^{10}$.

Parasite maintenance and rat infection procedures - This study was conducted using four different $S$. mansoni Brazilian strains: BE state of Pará $\left(01^{\circ} 28^{\prime} 03^{\prime \prime S}\right.$; 48 29'18"W), CM - state of Pernambuco $\left(08^{\circ} 00^{\prime} 08^{\prime \prime S} ; 35^{\circ} 01^{\prime} 06^{\prime \prime W}\right), \mathrm{CMO}$ - state of Rio Grande do Norte $\left(05^{\circ} 45^{\prime} 54^{\prime \prime} \mathrm{S} ; 35^{\circ} 12^{\prime} 04^{\prime \prime W}\right)$, and SJ - state of São Paulo (08 $45^{\prime} 48^{\prime \prime}$; $\left.34^{\circ} 54^{\prime} 47^{\prime \prime} \mathrm{W}\right)$. The life-cycle has been maintained through successive passages in SW mice and laboratory-reared sympatric snail: Biomphalaria glabrata (BE, CM and CMO strains) or B. tenagophila (SJ strain) for more than five years at Department of Malacology, Oswaldo Cruz Institute, Rio de Janeiro.

Groups of 10 rats (3-4 weeks), body weight (250-300 g) were infected by subcutaneous injection of $\sim 250$ cercariae from a single strain.

Parasite infection intensity - Stool samples were collected over a 24-h period, three times a week from each rat from day 42 until 61 following cercariae exposure. The feces were read in duplicate by the Kato-Katz method processed (Helminth Tec®, Belo Horizonte, Brazil) in order to determine the number of eggs per gram of stool (epg). The egg viability was determined according to the flame cell or/and miracidium motions in histological slides by light microscopy, as previously described ${ }^{21}$. On day 63 post-infection, all rats were killed by cervical dislocation. Adult worms were recovered from the portal system and mesenteric veins, counted in a stereomicroscope and infection rate was assessed as a percentage of cercariae that had matured into adult worms ${ }^{12}$.

Tissue egg counts - The intestines of infected rats were removed and divided into four equal regions of equal length (proximal, medial distal and cecum), as previously described ${ }^{33}$. After solubilization in $10 \% \mathrm{KOH}$ solution, eggs were counted under a light microscope, and values were extrapolated to the total organ content, as described elsewhere ${ }^{21}$. A fecundity index was calculated by the total number of eggs trapped in tissues divided by the total number of female worms.

Statistical analysis - Data analysis was performed using the Statistical Package for Social Sciences (SPSS) version 9.0. Groups were compared using Mann-Whitney, Regression and linear correlation tests and analysis of variance (One Way Anova) and the post-hoc test of Tukey. To assess correlation between variables, Pearson correlation test was used. $p \leq 0.05$ was considered as statistically significant.

\section{RESULTS}

Parasitological findings - All animals became infected. Egg laying began after 40 (BE and CM strains) or 42 days (CMO and SJ strains) of infection. Few eggs were present in the feces of $N$. squamipes during the first weeks of examination. The fecal egg-laying peaked on 47 (BE, CMO and SJ strains) or $51 \mathrm{dpi}$ (CM strain) and decreasing thereafter (Fig. 1). The animals infected with the CM strain presented highest egg excretion level than other strains. Viable eggs were observed in all experimental groups.

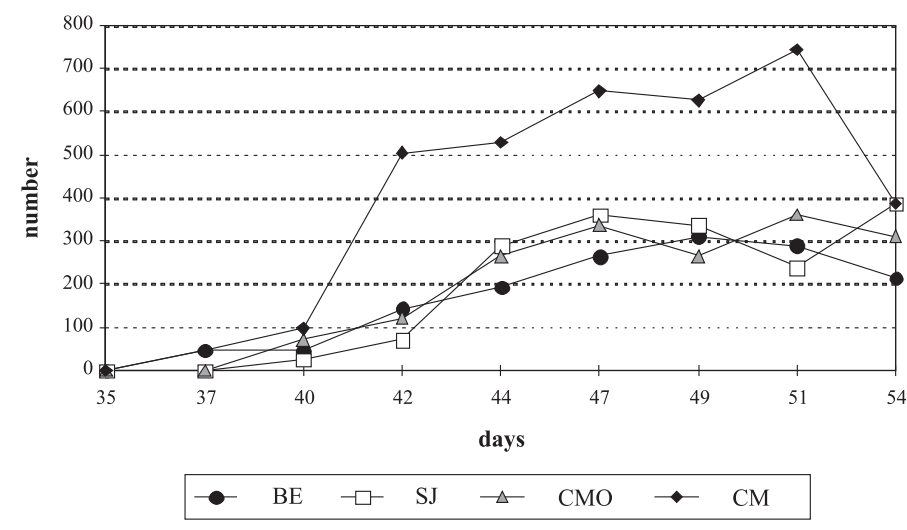

Fig. 1- Fecal egg-count in Nectomys squamipes experimentally-infected with Brazilian strains (BE, CM, SJ and CMO) of Schistosoma mansoni.

Regarding the pre-patent period and overall fecal egg counts no significant differences $(p>0.05)$ were found (Table 1). The BE strain presented lower infectivity and fecal egg excretion. Eggs concentrated mainly in the distal section in the small intestine (Fig. 2) everyone strain $(p=0.406)$. The cecum harbored fewer eggs however, significant differences $(p=0.0001)$ were observed: $1 \%$ (CMO), 3\% (CM), 7\% $(\mathrm{SJ})$ and $10 \%(\mathrm{BE})$. Regression and linear correlation analyses performed on the egg distribution demonstrated a correlation between tissue counts and total number of female worms $(p=0.001$ and $r=$

Table 1

Worm recovery and fecal egg count (mean and standard deviation) of Schistosoma mansoni strains (BE, SJ, CMO and CM) after experimental infection of Nectomys squamipes

\begin{tabular}{lll}
\hline Strains & Worm recovery & Fecal egg \\
\hline BE & $20.6 \pm 10.7$ & $168 \pm 114.5$ \\
SJ & $29.4 \pm 15.4$ & $189.3 \pm 163.4$ \\
CMO & $16.9 \pm 11.2$ & $192 \pm 144.5$ \\
CM & $29.2 \pm 15.4$ & $397.3 \pm 281.5$ \\
\hline
\end{tabular}

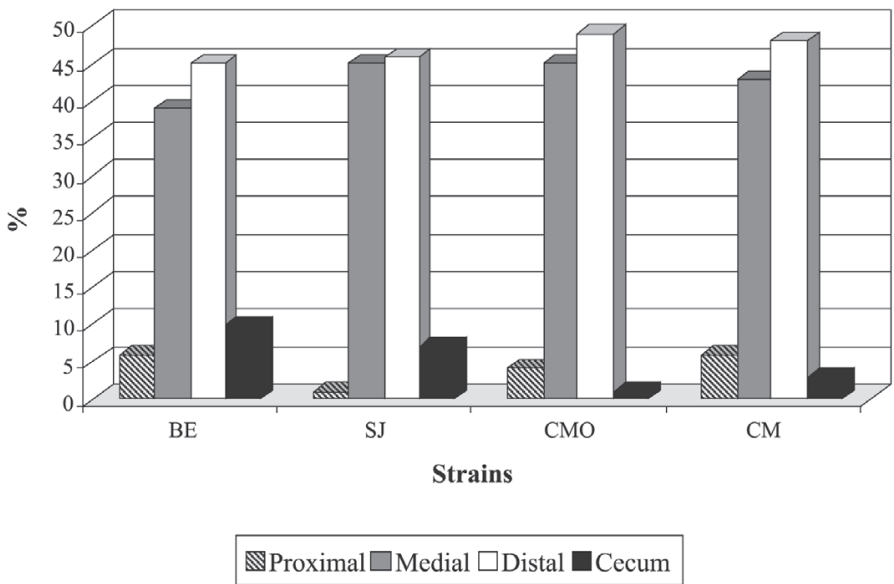

Fig. 2 - Location of Schistosoma mansoni eggs within sections in the small intestine (proximal, medial, distal) and large intestine (cecum) in experimentally-infected Nectomys squamipes with Schistosoma mansoni Brazilian strains (BE, CM, SJ and CMO). 
$0.885)$ and total fecal egg-laying $(p=0.005$ and $r=0.805)$, only for CM strain.

The infectivity rate was similar between SJ and CM strains $(29.4 \pm$ 15.4), BE $(20.6 \pm 10.7)$ and CMO $(16.9 \pm 11.2)$ strains (Table 1) however, no significant difference $(p=0.213)$ was found. The male/ female sex-ratio was 1:1.

\section{DISCUSSION}

The present findings pointed out the importance of obtaining comprehensive biological data, which should support epidemiological observations. Vertebrate hosts behave as biological filters to parasites selecting phenotypes and genotypes within natural populations ${ }^{8}$. Hence, parasites may recognize the physiological and biochemical conditions of their hosts that are of selective importance ${ }^{36}$. The ability to adjust growth and reproduction to immediate local conditions would have been of great interest adaptive value to parasites ${ }^{30}$. Moreover, a successful parasite established within the host is capable of developmental responses to host immune factors, which are closely linked to increase the probability of transmission ${ }^{7}$.

Preliminary investigations indicated that vertebrates host exerted strong influence on the morphological features of adult flatworms. The outcome of this interaction is that specimens maintained in other hosts rather than their normal ones display a phenotypic plasticity ${ }^{17,21,25,26}$. This result prompted us to next examine whether biological behavior is modified on account of the phenotypic plasticity.

The key issues in the occurrence of phenotypic plasticity are of biological and epidemiological relevancies. Regarding the experimental model employed here, biological characteristics were not affected, despite strains have been grown on mice for decades. It is worth emphasizing that all strains compared favorable with experiments using mice models. Adult worms attain "normal" dimensions ${ }^{16,27,29}$ and supernumerary testes lobes are found ${ }^{14,17,21,27}$. The biological characteristics were not affected, because the pre-patent period, tissue egg distribution and egg laying reproduced observations in mice ${ }^{15,21,28}$. Our results showed that CM strain presented highest egg excretion level than other strains. FERNANDEZ \& THIENGO ${ }^{11}$ have proved that five populations of Biomphalaria straminea from Goiás State located in the central part of Brazil were susceptible to this schistosome strain. Only CMO strain showed lower egg count in the large intestine. This finding may reflect differences in the wandering capacity among the strains ${ }^{37}$. The female transportation towards egg-laying site is subordinated to male's complex and well-developed musculature ${ }^{19,23}$. We have previously described biometric variations in worms from CMO strain $^{16}$.

In this study, overall results confirm that $N$. squamipes is a permissive host to $S$. mansoni $i^{17,18,20,32,33,34}$. It must be also emphasized that $S$. mansoni adult worms might detect signals from their environment and responding appropriately in a state-dependent manner could greatly enhance its fitness ${ }^{36}$. The present study highlights the importance of water rat as a reservoir host for $S$. mansoni strains that might contribute to dispersion of schistosomiasis mansoni in Brazil. Moreover, from a public health perspective, if schistosomiasis mansoni control program is to be instituted in areas where water rats are commom, the program should take into account their epidemiological role $^{13}$. More comparative studies are needed to investigate the occurrence of phenotypic plasticity among field $S$. mansoni strains.

\section{RESUMO}

\section{Implicações biológicas da plasticidade fenotípica no modelo Schistosoma mansoni - Nectomys squamipes}

O rato d'água Nectomys squamipes é importante transmissor nãohumano da esquistossomose. Durante a infecção experimental em $N$. squamipes, os vermes adultos apresentam plasticidade fenotípica. Esses achados levaram-nos a investigar se os aspectos biológicos também são afetados. Foram comparadas as características biológicas de quatro cepas de S. mansoni: BE (Estado de Belém do Pará), CM (Estado de Pernambuco), CMO (Estado do Rio Grande do Norte) e SJ (Estado de São Paulo), utilizando como modelo experimental $N$. squamipes criados e mantidos em laboratório. A infecção foi monitorada para a determinação do período pré-patente, eliminação de ovos nas fezes, viabilidade dos ovos, contagem de ovos retidos no intestino e infectividade. Nenhuma modificação biológica foi observada nesses parâmetros. Os resultados sugerem que o $N$. squamipes é susceptível a várias cepas de $S$. mansoni, contribuindo para a manutenção da esquistossomose no Brasil.

\section{ACKNOWLEDGMENTS}

To Maria de Fátima Bastos Martins for technical assistance, Dr. Lygia dos Reis Corrêa for kindly supply of parasites and Dr. Paulo Sérgio D'Andrea for water rat facilities.

\section{REFERENCES}

1. AlARCÓN DE NOYA, B.; POINTIER, J.P.; COLMENARES, C. et al. - Natural Schistosoma mansoni infection in wild rats from Guadeloupe: parasitological and immunological aspects. Acta trop., 68: 11-21, 1997.

2. ANTUNES, C.M.; MILWARD DE ANDRADE, R.; KATZ, N.; COELHO, P.M. \& PELLEGRINO, J. - Role of Nectomys squamipes squamipes in the epidemiology of Schistosoma mansoni. Ann. trop. Med. Parasit., 67: 67-73, 1973.

3. COSTA-SILVA, M.; RODRIGUES-SILVA, R.; HULSTIJN, M. et al. - Natural Schistosoma mansoni infection in Nectomys squamipes: histopathological and morphometric analysis in comparison to experimentally infected $N$. squamipes and C3H/He mice. Mem. Inst. Oswaldo Cruz, 97(suppl. 1): 129-142, 2002.

4. D'ANDREA, P.S.; FERNANDES, F.A.; CERQUEIRA, R. \& REY, L. - Experimental evidence and ecological perspectives for the adaptation of Schistosoma mansoni Sambon, 1907 (Digenea: Schistosomatidae) to a wild host, the water-rat, Nectomys squamipes Brants, 1827 (Rodentia: Sigmodontinae). Mem. Inst. Oswaldo Cruz, 97(suppl. 1): 11-14, 2002.

5. D'ANDREA, P.S.; HORTA, C.; CERQUEIRA, R. \& REY, L. - Breeding of the water rat (Nectomys squamipes) in the laboratory. Lab. Anim., 30: 369-376, 1996.

6. D'ANDREA, P.S.; MAROJA, L.S.; GENTILE, R. et al. - The parasitism of Schistosoma mansoni (Digenea-Trematoda) in a naturally infected population of water rats, Nectomys squamipes (Rodentia-Sigmodontinae) in Brazil. Parasitology, 120: 573$582,2000$.

7. DAVIES, S.J. \& McKERROW, J.H. - Developmental plasticity in schistosomes and other helminths. Int. J. Parasit., 33: 1277-1284, 2003. 


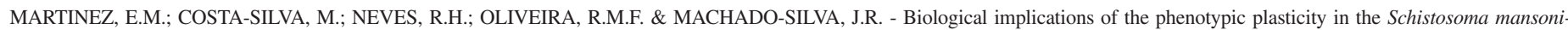
Nectomys squamipes model. Rev. Inst. Med. trop. S. Paulo, 50(4): 229-232, 2008.

8. DEANE, M.P.; MANGIA, R.H.; PEREIRA, N.M. et al. - Trypanosoma cruzi: strain selection by different schedules of mouse passage of an initially mixed infection. Mem. Inst. Oswaldo Cruz, 79: 495-497, 1984.

9. DUPLANTIER, J.M. \& SÈNE, M. - Rodents as reservoir hosts in the transmission of Schistosoma mansoni in Richard-Toll, Senegal, West Africa. J. Helminth., 74: 129$135,2000$.

10. ELLERY, A.W. - Guidelines for specification of animals and husbandry methods when reporting the results of animal experiments. Working Committee for the Biological Characterization of Laboratory Animals/GV-SOLAS. Lab. Anim., 19: 106-108, 1985.

11. FERNANDEZ, M.A. \& THIENGO, S.C. - Susceptibility of Biomphalaria straminea (Dunker, 1848) from Serra da Mesa Dam, Goiás, Brazil to infection with three strains of Schistosoma mansoni Sambon, 1907. Mem. Inst. Oswaldo Cruz, 97(suppl. 1): 59-60, 2002

12. FREIRE, N.; RODRIGUES-SILVA, R.; MACHADO-SILVA, J.R. \& REY, L. - A comparative parasitologic study on Biomphalaria glabrata snail and $\mathrm{C} 3 \mathrm{H} / \mathrm{He}$ mice infected with human and murine isolates of Schistosoma mansoni derived from Sumidouro, Rio de Janeiro, Brazil. Mem. Inst. Oswaldo Cruz, 98: 783-787, 2003.

13. GENTILE, R.; COSTA-NETO, S.F.; GONÇALVES, M.M. et al. - An ecological field study of the water-rat Nectomys squamipes as a wild reservoir indicator of Schistosoma mansoni transmission in an endemic area. Mem. Inst. Oswaldo Cruz, 101(suppl. 1): $111-117,2006$

14. HULSTIJN, M.; BARROS, L.A.; NEVES, R.H. et al. - Hermaphrodites and supernumerary testicular lobes in Schistosoma mansoni (Trematoda: Schistosomatidae) analyzed by brightfield and confocal microscopy. J. Parasit., 92: 496-500, 2006.

15. KASSIM, O.O.; CHEEVER, A.W. \& RICHARDS, C.S. - Schistosoma mansoni: mice infected with different worm strains. Exp. Parasit., 48: 220-224, 1979.

16. MACHADO-SILVA, J.R.; GALVÃO, C.; OLIVEIRA, R.M.; PRESGRAVE, O.A. \& GOMES, D.C. - Schistosoma mansoni Sambon, 1907: comparative morphological studies of some Brazilian strains. Rev. Inst. Med. trop. S. Paulo, 37: 441-447, 1995.

17. MACHADO-SILVA, J.R.; GALVÃO, C.; PRESGRAVE, O.A.; REY, L. \& GOMES, D.C. - Host-induced morphological changes of Schistosoma mansoni Sambon, 1907 male worms. Mem. Inst. Oswaldo Cruz, 89: 411-416, 1994.

18. MACHADO-SILVA, J.R.; LANFREDI, R.M. \& GOMES, D.C. - Morphological study of adult male worms of Schistosoma mansoni Sambon, 1907 by scanning electron microscopy. Mem. Inst. Oswaldo Cruz, 92: 647-653, 1997.

19. MAIR, G.R.; MAULE, A.G.; SHAW, C. \& HALTON, D.W. - Muscling in on parasitic flatworms. Parasit. today, 14: 73-76, 1998.

20. MALDONADO Jr., A.; MACHADO E SILVA, J.R.; RODRIGUES E SILVA, R.; LENZI, H.L. \& REY, L. - Evaluation of the resistance to Schistosoma mansoni infection in Nectomys squamipes (Rodentia: Cricetidae), a natural host of infection in Brazil. Rev. Inst. Med. trop. S. Paulo, 36: 193-198, 1994.

21. MARTINEZ, E.M.; NEVES, R.H.; OLIVEIRA, R.M.; MACHADO-SILVA, J.R. \& REY, L. - Características biológicas e morfológicas de cepas brasileiras de Schistosoma mansoni em Mus musculus. Rev. Soc. bras. Med. trop., 36: 557-564, 2003.

22. MODENA, C.M.; COELHO, P.M.; BARBOSA, F.S. \& LIMA, W.S. - Transmission of Schistosoma mansoni under experimental conditions using the bovineBiomphalaria glabrata-bovine model. Rev. Inst. Med. trop. S. Paulo, 35: 11-16, 1993
23. MORAND, S. \& MULLER-GRAF, C.D. - Muscles or testes? Comparative evidence for sexual competition among dioecious blood parasites (Schistosomatidae) of vertebrates. Parasitology, 120: 45-56, 2000.

24. MORAND, S.; POINTIER, J.P. \& THERON, A. - Population biology of Schistosoma mansoni in the black rat: host regulation and basic transmission rate. Int. J. Parasit., 29: 673-684, 1999 .

25. MOUHAID, G.; CASANOVA, J.C. \& MONÉ, H. - Plasticidad fenotípica y determinación sistemática de parásitos: el caso de Echinoparyphium elegans. Acta Parasit. Portuguesa, 4: 127, 1997.

26. NEVES, R.H.; COSTA-SILVA, M.; MARTINEZ, E.M. et al. - Phenotypic plasticity in adult worms of Schistosoma mansoni (Trematoda:Schistosomatidae) evidenced by brightfield and confocal laser scanning microscopies. Mem. Inst. Oswaldo Cruz, 99: $131-136,2004$

27. NEVES, R.H.; PEREIRA, M.J.; OLIVEIRA, R.M.; GOMES, D.C. \& MACHADO-SILVA J.R. - Schistosoma mansoni Sambon, 1907: morphometric differences between adult worms from sympatric rodent and human isolates. Mem. Inst. Oswaldo Cruz, 93(suppl. 1): 309-312, 1998.

28. NYINDO, M. \& FARAH, I.O. - The baboon as a non-human primate model of human schistosome infection. Parasit. today, 15: 478-482, 1999.

29. PARAENSE, W.L. \& CORREA, L.R. - Observations on two biological races of Schistosoma mansoni. Mem. Inst. Oswaldo Cruz, 76: 287-291, 1981.

30. POULIN, R. - The evolution of life history strategies in parasitic animals. Advanc. Parasit., 37: 107-134, 1996.

31. REY, L. - Non-human vertebrate host of Schistosoma mansoni and schistosomiasis transmission in Brazil. Res. Rev. Parasit., 53: 13-25, 1993.

32. RIBEIRO, A.C.; MALDONADO JUNIOR, A.; D'ANDREA, P.S.; VIEIRA, G.O. \& REY, L. - Susceptibility of Nectomys rattus (Pelzen, 1883) to experimental infection with Schistosoma mansoni (Sambon, 1907): a potential reservoir in Brazil. Mem. Inst. Oswaldo Cruz, 93: 295-299, 1998.

33. RODRIGUES E SILVA, R.; MACHADO E SILVA, J.R.; FAERSTEIN, N.F.; LENZI, H.L. \& REY, L. - Natural infection of wild rodents by Schistosoma mansoni. Parasitological aspects. Mem. Inst. Oswaldo Cruz, 87(suppl. 1): 271-276, 1992.

34. SOUZA, V.A.; RODRIGUES E SILVA, R.; MALDONADO JUNIOR, A.; MACHADO E SILVA, J.R. \& REY, L. - Nectomys squamipes (Rodentia: Cricetidae) as an experimental model for Schistosomiasis mansoni. Mem. Inst. Oswaldo Cruz, 87 (suppl. 1): 277-280, 1992.

35. THERON, A.; POINTIER, J.P.; MORAND, S.; IMBERT-ESTABLET, D. \& BOREL, G. - Long-term dynamics of natural populations of Schistosoma mansoni among Rattus rattus in patchy environment. Parasitology, 104: 291-298, 1992.

36. THOMAS, F.; BROWN, S.P.; SUKHDEO, M. \& RENAUD, F. - Understanding parasite strategies: a state-dependent approach? Trends Parasit., 18: 387-390, 2002.

37. VALADARES, T.E.; COELHO, P.M.; PELLEGRINO, J. \& SAMPAIO, I.B. - Schistosoma mansoni: comparação da oviposição entre as cepas LE (Belo Horizonte), SP (São Paulo) e ST (Liberia) em camundongos. Rev. Inst. Med. trop. S. Paulo, 23: 1-5, 1981

38. YOSHIOKA, L.; ZANOTTI-MAGALHÃES, E.M.; MAGALHÃES, L.A. \& LINHARES A.X. - Schistosoma mansoni: a study of pathogenesis of Santa Rosa strain (Campinas, SP, Brasil) in mice. Rev. Soc. bras. Med. trop., 35: 203-207, 2002.

Received: 22 February 2008

Accepted: 30 June 2008 